\title{
Leaching Titaniferous Magnetite Concentrate by Alkaline Aqueous Solution
}

\author{
Ke Guo $^{1,2} \cdot$ Shaoyan Wang ${ }^{1} \cdot$ Renfeng Song ${ }^{2} \cdot$ Zhiqiang Zhang $^{1}$ \\ Received: 2 August 2020 / Accepted: 18 January 2021 / Published online: 16 June 2021 \\ (C) The Author(s) 2021
}

\begin{abstract}
Leaching titaniferous magnetite concentrate with alkali solution of high concentration under high temperature and high pressure was utilized to improve the grade of iron in iron concentrate and the grade of $\mathrm{TiO}_{2}$ in titanium tailings. The titaniferous magnetite concentrate in use contained $12.67 \% \mathrm{TiO}_{2}$ and $54.01 \% \mathrm{Fe}$. The thermodynamics of the possible reactions and the kinetics of leaching process were analyzed. It was found that decomposing $\mathrm{FeTiO}_{3}$ with $\mathrm{NaOH}$ aqueous solution could be carried out spontaneously and the reaction rate was mainly controlled by internal diffusion. The effects of water usage, alkali concentration, reaction time, and temperature on the leaching procedure were inspected, and the products were characterized by X-ray diffraction, scanning electron microscope, and energy dispersive spectroscopy, respectively. After $\mathrm{NaOH}$ leaching and magnetic separation, the concentrate, with $\mathrm{Fe}$ purity of $65.98 \%$ and $\mathrm{Fe}$ recovery of $82.46 \%$, and the tailings, with $\mathrm{TiO}_{2}$ purity of $32.09 \%$ and $\mathrm{TiO}_{2}$ recovery of $80.79 \%$, were obtained, respectively.
\end{abstract}

Keywords Titaniferous magnetite concentrate $\cdot$ Leaching process $\cdot$ Separation

\section{Introduction}

Titaniferous magnetite ore (TMO) can be utilized for production of pig iron as main product and titanium compound as byproduct [1]. The ore is a kind of symbiotic magnetite, mainly in the form of magnetite, and contains a small amount of ilmenite and titanomagnetite $[2,3]$. TMO is hard to be dissociated into monomer. In the existing iron concentrating process, TMO goes into iron concentrate, and ilmenite goes into concentrate and tailings. The concentrated TMO contains more than $10 \% \mathrm{TiO}_{2}$, where the available iron grade is not high, and moreover, titanium enters into blast furnace slag

Renfeng Song

srfandwl@163.com

$\triangle$ Zhiqiang Zhang

zzq@ustl.edu.cn

Ke Guo

asgk2006@sina.com

Shaoyan Wang

aswsy64@163.com

1 School of Chemical Engineering, University of Science \& Technology Liaoning, Anshan 114051, Liaoning, China

2 Anshan Iron and Steel Group Corp, Mining Design and Research Institute, Anshan 114001, Liaoning, China during the iron smelting procedure and cannot be economically recovered [4]. Due to the inherent dense structure and the symbiotic relationship between iron and titanium in TMO, only by making titanium and iron dissociate on the lattice level, can we get high quality iron concentrate and titanium tailings. Therefore, TMO as a typical poly metallic paragenic source of iron is difficult to treat [5]. The separation of titanium and iron from ilmenite is completed by chemical process. Pre-reduction is the thermo-chemical beneficiation process which is very useful technique for upgradation of metal values from complex low grade ore. The previous research has been based on lump TMO by gas-solid and solid-solid reduction, but the degree of reducibility is not very high and most of the ilmenite grains are irreducible [6]. The carbon- or hydrogenbased reduction is used in common [7-12]. Pre-treatment by multiple heating to high temperature (1373 K and $1473 \mathrm{~K}$, respectively) and subsequently sudden cooling to room temperature by water successfully increase the porosity as well as many fissures in dense grain, which significantly enhance the degree of reduction of TMO [13]. Studies have been reported by various researchers on the effects of pre-oxidation, the addition of alkali metals such as sodium sulfate, sodium carbonate, borax, and ferrosilicon for enhancing the reducibility of TMO [14]. B.C. JENA et al. [15] used a combined hot-wet process to recover iron and titanium from the vanadiumtitanium magnetite deposit. Selective reduction smelting of 
the ore can achieve a titanium recovery rate of more than $90 \%$. Zhao et al. [16] proposed a method for extracting iron, vanadium, and titanium from titanium magnetite concentrates, mainly through concentrate reduction, magnetic separation, and hydrochloric acid treatment of titanium-containing tailings slag. This new process can realize the recovery of iron and titanium; the rates were $88.3 \%$ and $93.7 \%$, respectively. Chen et al. [17] used molten salt roasting and water leaching processes to treat titanium magnetite concentrate, and the recovery rate of titanium in the titanium-rich slag reached $96.3 \%$ under the optimal process conditions.

Due to high temperature and energy consumption for ilmenite reduction, most processes mentioned above still have not yet been employed industrially. Therefore, it is of great significance to study the separation of titanium and iron in titaniferous magnetite concentrate. In this paper, highpressure alkaline leaching method was used to obtain highquality iron concentrate and titanium tailings from TMO by means of the impregnating and etching effects of high concentration $\mathrm{NaOH}$ aqueous solution.

\section{Experimental}

\subsection{Raw Material}

Titanium magnetite concentrate is a mineral obtained after iron beneficiation of titanium magnetite from the Midi Concentrator in Panzhihua, China. The titanium magnetite concentrate particle size is fine, and the content of minerals with a particle size of less than $0.074 \mathrm{~mm}$ reaches about $62 \%$. Its compositions were expressed as the forms of $\mathrm{Fe}_{2} \mathrm{O}_{3}, \mathrm{FeO}$, $\mathrm{TiO}_{2}$, etc., and listed in Table 1 . The major contents were $12.67 \% \mathrm{TiO}_{2}$ and $54.01 \% \mathrm{Fe}$. The phase analysis results of the vanadium-titanium magnetite concentrate are shown in Table 2 and 3.

\subsection{Experimental Procedure}

In order to ensure the representativeness of the test sample, this experiment adopts the method of sample splitting. Weigh $5 \mathrm{~kg}$ of mineral powder and reduce the mass to $150 \mathrm{~g}$ after sample splitting, the leaching reaction of $150 \mathrm{~g}$ titaniferous magnetite concentrate with a certain amount of $\mathrm{NaOH}$ aqueous solution was carried out in a sealed autoclave $(1 \mathrm{~L}$ capacity, Parr, the USA). The operational process was to fill the autoclave with the materials, tighten the cover, purge the reactor with $\mathrm{N}_{2}$, and then stir the mixture at $600 \mathrm{r} / \mathrm{min}$; meanwhile, heat the autoclave, after keeping the mixture react at a temperature between 300 and $400{ }^{\circ} \mathrm{C}$ for a certain time, cool the mixture to room temperature, and filter, wash, and dry the powder. Magnetic separation tube (XCGS- $\Phi$ 50, China) with the largest magnetic induction intensity of $250 \mathrm{KA} / \mathrm{M}$ was used to separate the powder to obtain iron concentrate and titanium tailings at an electric current of $1.25 \mathrm{~A}$. Figure 1 depicts the process flow. The high-pressure reactor of instrument parameters and the main technical parameters of magnetic tube are shown in Tables 4 and 5, respectively.

\subsection{Analysis}

The determination of $\mathrm{Fe}$ (total iron) content and $\mathrm{TiO}_{2}$ content in the samples were performed by using the potassium dichromate volumetric method and the ammonium ferric sulfate volumetric method, respectively. The characterization of phase composition and morphology of the solid samples were performed on an X-ray diffractometer (XRD: X'Pert Powder, PANalytical B.V., Netherlands), scanning electron microscopy (SEM: ZEISS, IGMAHD), and energy dispersive spectroscopy (EDS: Oxford, X-Max).

\section{Results and Discussion}

\subsection{Thermodynamic Analysis}

In Fig. 2 of characterization of the raw mineral in use, XRD spectrum revealed that the mineral mainly consisted of ilmenite in space group of rhombohedral, of which the main diffraction peak and sub-strong diffraction peak are $32.59^{\circ}$ and $35.23^{\circ}$; SEM picture showed the dense appearance of the raw mineral, EDS of the designed area exhibited $\mathrm{Ti}$, and $\mathrm{Fe}$ distribution in uniform and EDS of the marking point provided the weight percentage of $34.13 \% \mathrm{Fe}$ and $31.28 \% \mathrm{Ti}$. The mineral feature determined chemical separation rather than physical separation. Therefore, we used the chemical reaction of ilmenite with $\mathrm{NaOH}$ aqueous solution to leach Ti element and separate Ti and Fe.

The three possible leach reactions were as follows.

$$
\begin{aligned}
& 2 \mathrm{NaOH}+\mathrm{FeTiO}_{3}=\mathrm{Na}_{2} \mathrm{TiO}_{3}+\mathrm{FeO}+\mathrm{H}_{2} \mathrm{O} \\
& 2 \mathrm{NaOH}+2 \mathrm{FeTiO}_{3}=\mathrm{Na}_{2} \mathrm{Ti}_{2} \mathrm{O}_{5}+2 \mathrm{FeO}+\mathrm{H}_{2} \mathrm{O} \\
& 2 \mathrm{NaOH}+3 \mathrm{FeTiO}_{3}=\mathrm{Na}_{2} \mathrm{Ti}_{3} \mathrm{O}_{7}+3 \mathrm{FeO}+\mathrm{H}_{2} \mathrm{O}
\end{aligned}
$$

Table 1 The compositions in the expressed forms of the titaniferous magnetite concentrate

\begin{tabular}{lcccccccccc}
\hline The expressed forms & $\Sigma \mathrm{Fe}$ & $\mathrm{Fe}_{2} \mathrm{O}_{3}$ & $\mathrm{FeO}$ & $\mathrm{TiO}_{2}$ & $\mathrm{Al}_{2} \mathrm{O}_{3}$ & $\mathrm{~S}$ & $\mathrm{SiO}_{2}$ & $\mathrm{MgO}$ & $\mathrm{CaO}$ & $\mathrm{V}_{2} \mathrm{O}_{5}$ \\
\hline Content (mass \%) & 54.01 & 40.97 & 32.42 & 12.67 & 3.30 & 0.57 & 3.21 & 2.90 & 0.98 & 0.61 \\
\hline
\end{tabular}


Table 2 Results of iron chemical phase analysis in the vanadium-titanium magnetite concentrate

\begin{tabular}{|c|c|c|c|c|c|c|c|c|}
\hline \multirow[t]{2}{*}{ Ore sample } & \multirow[t]{2}{*}{ Project } & \multicolumn{7}{|c|}{ Iron chemical phase } \\
\hline & & Magnetite & Hematite and limonite & Ilmenite & Iron carbonate & Iron sulfide & Ferrosilite & Total \\
\hline \multirow[t]{3}{*}{ Raw ore } & Content & 50.78 & 1.46 & 0.26 & 0.16 & 1.12 & 0.23 & 54.01 \\
\hline & Distribution rate & 94.02 & 2.70 & 0.48 & 0.30 & 2.07 & 0.43 & 100.00 \\
\hline & Cumulative distribution rate & 94.02 & 96.72 & 97.20 & 97.50 & 99.57 & 100.00 & - \\
\hline
\end{tabular}

The Gibbs free energy change $\Delta G$ of a reaction is obtained by Eq. (1).

$\Delta G=\Delta G^{\Theta}+R T \ln \frac{P_{\mathrm{H}_{2} \mathrm{O}}}{p^{\Theta}}$

where $\Delta G^{\Theta}$ is the standard Gibbs free energy change, $R$ the ideal gas constant, $8.314 \mathrm{~J} \cdot \mathrm{K}^{-1} \cdot \mathrm{mo} \Gamma^{-1}, T$ the reaction temperature, $P_{\mathrm{H}_{2} \mathrm{O}}$ is the vapor pressure of water, and $p^{\Theta}=1 \mathrm{~atm}$.

The leaching reaction was carried out in a closed hightemperature and high-pressure reactor, with water usage of $210-480 \mathrm{~g}$. The curve of actual pressure changing with temperature ( $P-T$ curve) was shown in Fig. 3, where the pressure range was $1-180 \mathrm{~atm}$. According to the three-phase balance diagram of water [18], water existed in a gaseous form under the above conditions. Therefore, the influence of the vapor pressure of water $P_{\mathrm{H}_{2} \mathrm{O}}$ on reaction thermodynamics must be considered. The reaction system pressure was mainly controlled by the amount of water.

According to the heat capacity, standard enthalpy and entropy of each material involved in the reaction equation; $\Delta G^{\Theta}$ was calculated. Combining the experimental measured $P$ - $T$ curves under different water usages, $\Delta G-T$ curves of each leaching reaction were computed, as shown in Fig. 3.

Figure 3 showed that under the conditions of the temperature of $100-400^{\circ} \mathrm{C}$ and the water usage of $210-480 \mathrm{~g}$, the $\Delta G$ values of the three reactions were less than zero, indicating that leaching titanium from ilmenite with $\mathrm{NaOH}$ aqueous solution was a spontaneous process. With the increase of the temperature, $\Delta G$ decreased, so the higher temperature was advantageous to the titanium leaching and the more favorable for the reactions (3). When the temperature was higher than about $300{ }^{\circ} \mathrm{C}$, the $\Delta G$ values of reactions (1) and (2) increased. Of the three reactions, reaction (2) was more likely to occur under the same temperature. $\Delta G$ of each reaction was also impacted by water usage. With the increase of the water usage, $\Delta G$ increased, and when the water usage was higher than about $410 \mathrm{~g}$, the $\Delta G$ change got smaller.

Due to the complex composition of the ore, the dissolution was complicated under the conditions of high temperature, pressure, and concentrated alkali. These three products might not be the final products. As a preliminary reaction, the leaching process was completely thermodynamically feasible.

\subsection{Kinetic Analysis}

Titanium leaching occurred when $\mathrm{NaOH}$ reacted with titaniferous magnetite concentrate, so it was considered that the reaction process was applicable to the shrinkage core model [19]. According to the linear correlation coefficients of Eq. (2) and Eq. (3), the kinetic control steps of the reaction process were judged.

$1-(1-X)^{1 / 3}=k t$

$1+2(1-X)-3(1-X)^{2} / 3=k t$

where $t$ is the reaction time, $k$ the rate constant, and $X$ the extent of reaction (i.e., $0=$ no reaction, $1=$ complete digestion). Equation (2) represents that chemical reactions at the surface is the main determinant of reaction rate; Equation (3) represents that diffusion through a reacted layer of increasing thickness is the main determinant of reaction rate.

Base on the recovery $(X)$ of $\mathrm{TiO}_{2}$ in tailings obtained experimentally under three different leaching conditions, the relationships between $1+2(1-X)-3(1-X)^{2} / 3$ and reaction time and between $1-(1-X)^{1 / 3}$ and reaction time were
Table 3 Results of titanium chemical phase analysis in the vanadium-titanium magnetite concentrate

\begin{tabular}{llllll}
\hline Ore sample & Project & \multicolumn{2}{l}{ Titanium chemical phase } & \\
\cline { 3 - 6 } & & Titanomagnetite & Ilmenite & Silicate & Total \\
\hline \multirow{2}{*}{ Raw ore } & Content & 11.56 & 0.85 & 0.26 & 12.67 \\
& Distribution rate & 91.24 & 6.71 & 2.05 & 100.00 \\
& Cumulative distribution rate & 91.24 & 97.95 & 100.00 & - \\
\hline
\end{tabular}




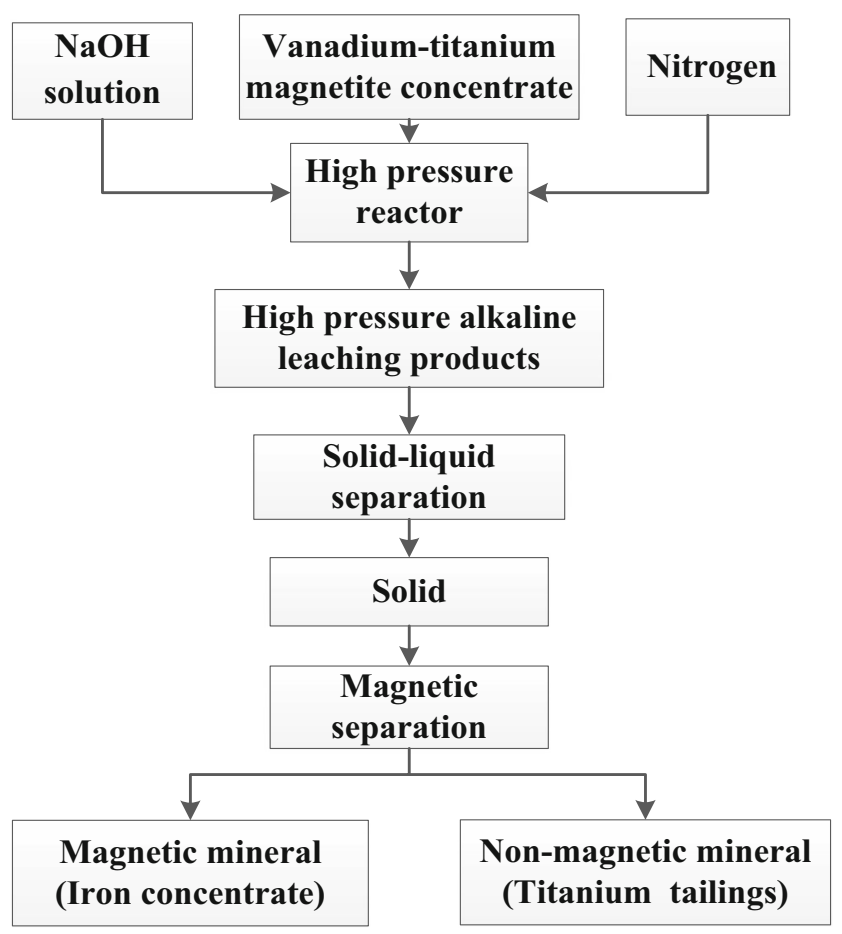

Fig. 1 Flow chart of the high-pressure alkali leaching-magnetic separation process

obtained (see Fig. 4). Comparison with the two relationships under the same leaching condition indicated a better linear relation between $1+2(1-X)-3(1-X)^{2 / 3}$ and reaction time. Therefore, product diffusion was considered the control factor of reaction rate. Furthermore, it was found that the linear correlation coefficient in Eq. (3), obtained in case (c) under higher reaction temperature, was doubled as compared with cases (a) and (b).

\subsection{Product Characterization}

\subsubsection{Concentrates}

SEM images of concentrates $\mathrm{C} 1-\mathrm{C} 9$ in Fig. 5 showed that there were signs of etching effect on concentrate $\mathrm{C} 1 \mathrm{ob}-$ tained by $150 \mathrm{~g}$ ore reacting with $40 \% \mathrm{NaOH}$ in $410 \mathrm{~g}$ water at $300{ }^{\circ} \mathrm{C}$ only after $15 \mathrm{~min}$; after $30 \mathrm{~min}$, the parallel grooves on concentrate $\mathrm{C} 2$ were produced; for concentrate $\mathrm{C} 3$ obtained after $60 \mathrm{~min}$, the surface of the large grain was etched into grid grooves, while the edges
Table 5 The main technical parameters of magnetic tube

\begin{tabular}{lll}
\hline Name & XCGS- $\$ 50$ magnetic tube & Unit \\
\hline Glass tube diameter & 50 & $\mathrm{~mm}$ \\
2 Magnetic pole head gap & 52 & $\mathrm{~mm}$ \\
Magnetic induction & $0-250$ & $\mathrm{KA} / \mathrm{M}$ \\
Excitation power & $<500$ & $\mathrm{VA}$ \\
Sample size & $\leq 0.5$ & $\mathrm{~mm}$ \\
Moving stroke & 40 & $\mathrm{~mm}$ \\
Vibration frequency & 70 & 次 $/ \mathrm{min}$ \\
Motor Power & 120 & $\mathrm{~W}$ \\
\hline
\end{tabular}

and corners of the small particles were no longer clear; after $120 \mathrm{~min}$, the gridded ravines of concentrate $\mathrm{C} 4$ were deepened, the small cubic particles of $300-650 \mathrm{~nm}$ appeared on the observed big grain, and some of them fell off; after $180 \mathrm{~min}$, there still existed the particles hard to be etched in concentrate $\mathrm{C} 5$; when reacting at $320{ }^{\circ} \mathrm{C}$ for $1 \mathrm{~h}$, the etching effect on concentrate $\mathrm{C} 6$ was heavier than that of $\mathrm{C} 3$; with the increase of temperature to $360{ }^{\circ} \mathrm{C}$, concentrate $\mathrm{C} 7$ was etched into finer cubic particles, about 250-500 nm in size; for concentrate $\mathrm{C} 8$ obtained by etching $150 \mathrm{~g}$ ore with $293 \mathrm{~g} \mathrm{NaOH}$ and $210 \mathrm{~g}$ water at $340{ }^{\circ} \mathrm{C}$ for $1 \mathrm{~h}$, the surface etching was much heavier that the size of the etched particles became much smaller, 200-400 nm, because of the high $\mathrm{NaOH}$ concentration of $58.25 \% \mathrm{w} / \mathrm{w}$, but the deeper leaching did not take place due to high viscosity of the reaction medium; with the increase of the water usage to $315 \mathrm{~g}$, the etching effect on or under surface was much heavier that the edges of the formed cube particles became much rounded and more gaps and voids appeared on concentrate C9.

The data in Table 4 of EDS measurements of marking points on SEM photographs of concentrates C1-C9 in Fig. 5 indicated that the leaching reaction was rapid and titanium on the surface of $\mathrm{C} 1$ was significantly reduced at $15 \mathrm{~min}$; with the extension of time, the ratio of iron to titanium on the surface of some mineral particles, such as $\mathrm{C} 2-1$ or $\mathrm{C} 2-2, \mathrm{C} 3-1$ or $\mathrm{C} 3-2$, and $\mathrm{C} 5$, did not change any more, and on the surface of other mineral particles, such as $\mathrm{C} 4-1$ or $\mathrm{C} 4-2$ increased further $(\mathrm{C} 2-1$ and $\mathrm{c} 2-2$ were the marking points observed on the surface of a same grain of sample $\mathrm{C} 2 ; \mathrm{C} 3-1$ and $\mathrm{c} 3-2$ the points of a bigger
Table 4 The high-pressure reactor of instrument parameters

\begin{tabular}{llll}
\hline Capacity $(\mathrm{L})$ & Inside diameter $(\mathrm{mm})$ & Kettle deep $(\mathrm{mm})$ & Stirring diameter $(\mathrm{mm})$ \\
\hline 1 & 95.25 & 156.9 & 40 \\
Power $(\mathrm{kw})$ & Limit temperature $\left({ }^{\circ} \mathrm{C}\right)$ & Limit pressure $(\mathrm{Mpa})$ & Heating rate $\left({ }^{\circ} \mathrm{C} / \mathrm{min}\right)$ \\
2.5 & 500 & 34.44 & 5 \\
\hline
\end{tabular}


Fig. 2 XRD pattern and SEM image of the raw mineral

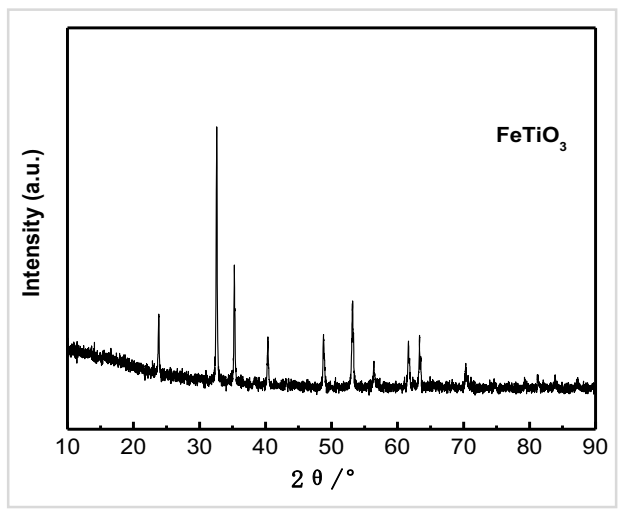

grain and a smaller particle of sample $\mathrm{C} 3$, respectively; C4-1 and c4-2 the points of a eroded grain and a broken grain of sample $\mathrm{C} 4$, respectively); with the increase of temperature, the ratio of iron to titanium on the surface of C3-2, C6, and C7 increased; with the increase of water usage, the ratio of iron to titanium on the surface of $\mathrm{C} 8$ and C9 increased, either (Table 6).

XRD spectra of concentrates $\mathrm{C} 1-\mathrm{C} 9$ in Fig. 6 displayed that the main diffraction peak of ilmenite almost disappeared in concentrate $\mathrm{C} 1$ and did not exist in concentrates $\mathrm{C} 2-\mathrm{C} 9$, proving that the leaching reaction rate was fast at low temperature; the appeared diffraction peaks belonged to $\mathrm{Fe}_{3} \mathrm{O}_{4}$ in the space group of
Cubic Fd-3 m, of which the main diffraction peak and sub-strong diffraction peak are $35.44^{\circ}$ and $62.55^{\circ}$, respectively. $\mathrm{FeO}$, as the product of the leach reaction, was easy to be oxidized by $\mathrm{O}_{2}$ dissolved in $\mathrm{NaOH}$ aqueous solution during washing and filtering processes and changed into $\mathrm{Fe}_{3} \mathrm{O}_{4}$.

\subsubsection{Tailings}

Corresponding to $\mathrm{C} 1-\mathrm{C} 9$ concentrates, there were tailings T1-T9, respectively. SEM images of tailings T1-T9 in Fig. 7 showed that under conditions of $150 \mathrm{~g}$ ore, $40 \%$ $\mathrm{NaOH}, 410 \mathrm{~g}$ water, and reacting at $300{ }^{\circ} \mathrm{C}$, when the
Fig. $3 P$ - $T$ curves of water gaseous and $\Delta G-T$ curves of reactions (1)-(3) under different water usages (a $150 \mathrm{~g}, \mathrm{~b} 210 \mathrm{~g}$, c 315 g, d 410 g, e 480 g)
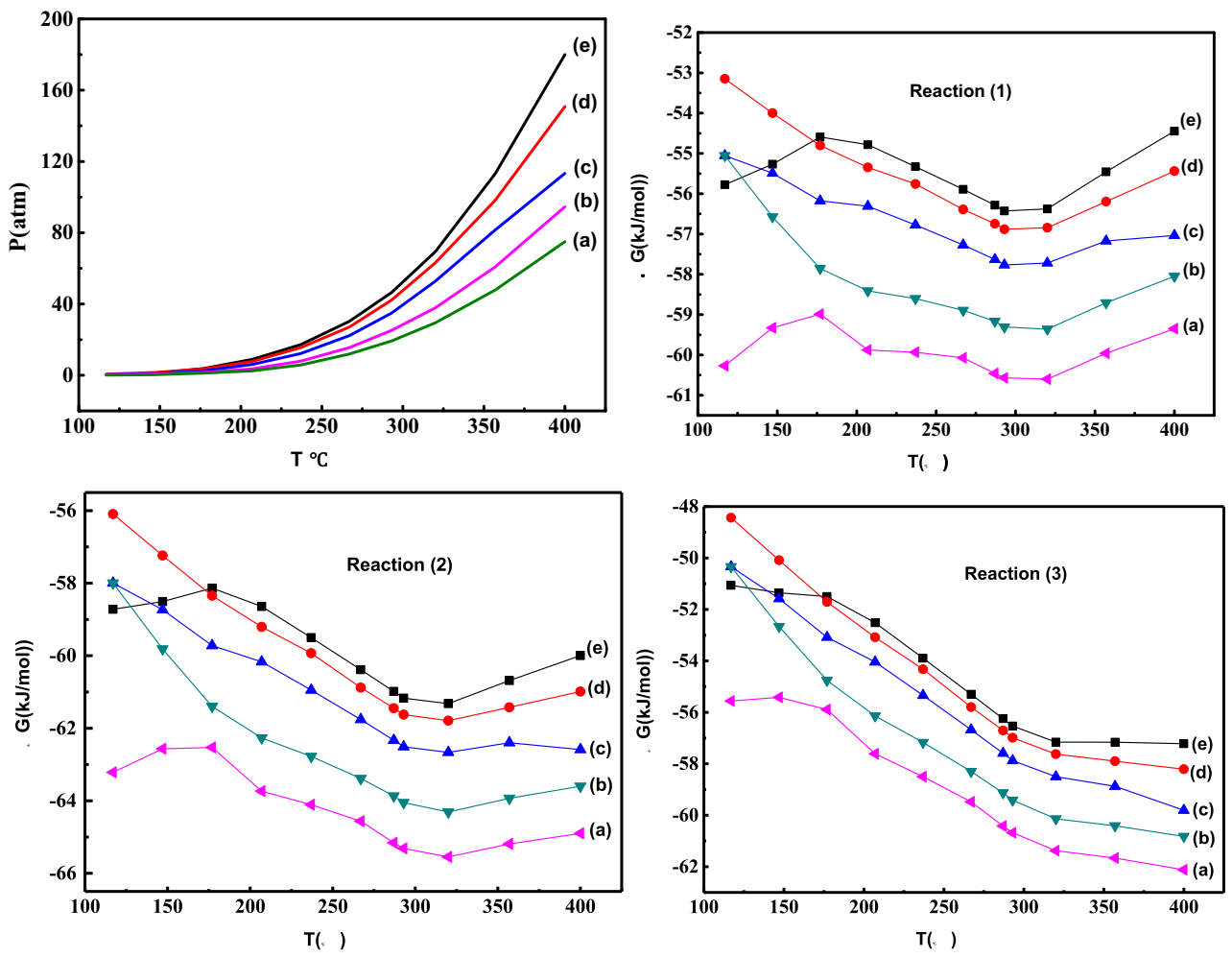
Fig. 4 Relationships between 1$(1-X)^{1 / 3}$ and time and between 1 $+2(1-X)-3(1-X)^{2 / 3}$ and time (In the cases of (a) temperature $300{ }^{\circ} \mathrm{C}, \mathrm{NaOH}$ concentration $40 \%$, and water usage $410 \mathrm{~g}$; (b) temperature $310{ }^{\circ} \mathrm{C}, \mathrm{NaOH}$ concentration $45 \%$, and water usage $315 \mathrm{~g}$; (c) temperature $320^{\circ} \mathrm{C}, \mathrm{NaOH}$ concentration $40 \%$, and water usage $410 \mathrm{~g}$ )
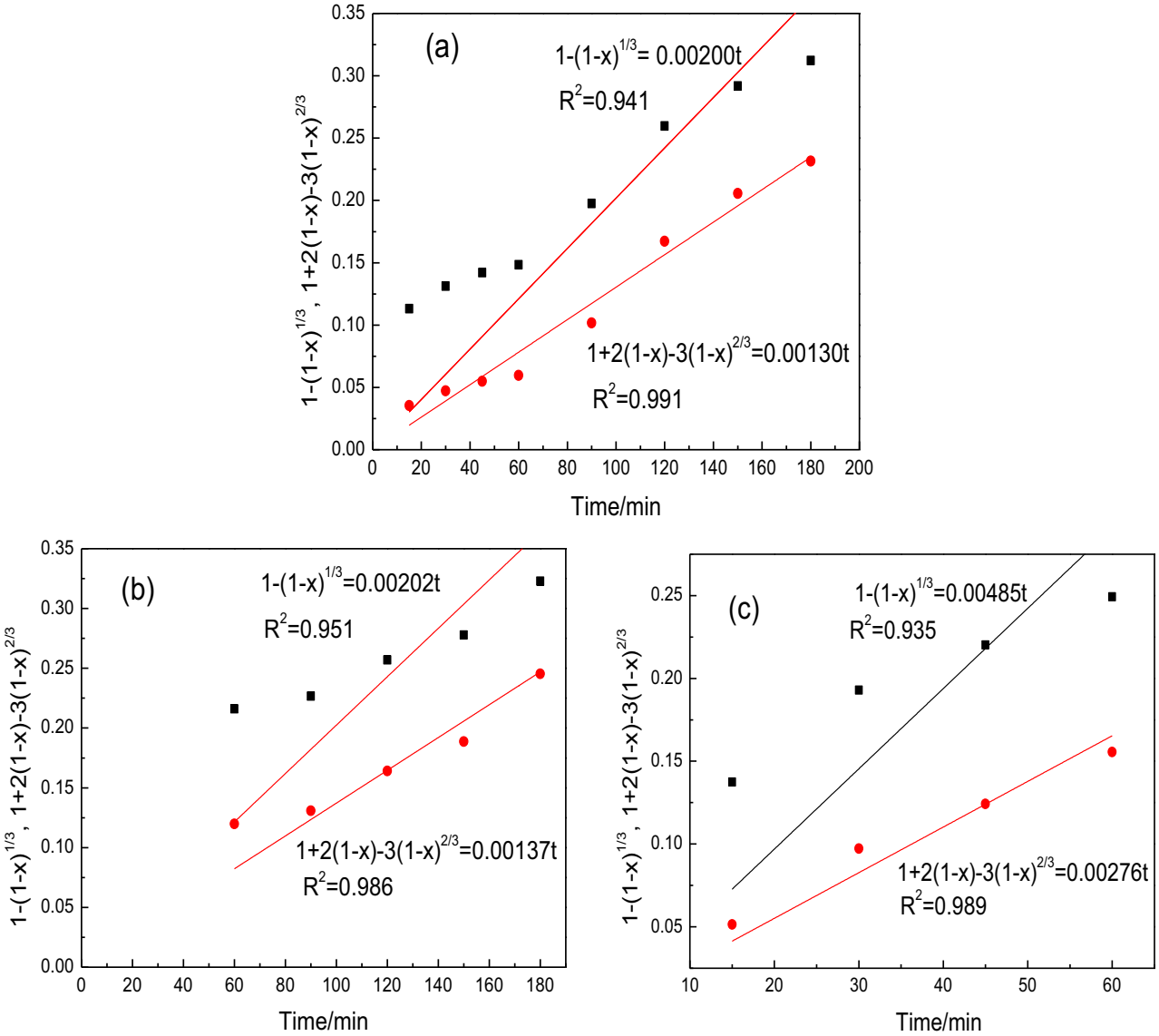

Fig. 5 SEM images of concentrates C1-C9 (concentrates $\mathrm{C} 1-\mathrm{C} 5$ obtained under the conditions of $150 \mathrm{~g}$ ore, $300{ }^{\circ} \mathrm{C}$, $40 \% \mathrm{NaOH}, 410 \mathrm{~g}$ water, and different reaction times of $15 \mathrm{~min}$, $30 \mathrm{~min}, 60 \mathrm{~min}, 90 \mathrm{~min}$, and 120 min, respectively; concentrates $\mathrm{C} 6-\mathrm{C} 7$ obtained under the conditions of $150 \mathrm{~g}$ ore, $40 \%$ $\mathrm{NaOH}, 410 \mathrm{~g}$ water, $60 \mathrm{~min}$, and different reaction temperatures of $320^{\circ} \mathrm{C}$ and $360{ }^{\circ} \mathrm{C}$, respectively; concentrates $\mathrm{C} 8$ - $\mathrm{C} 9$ obtained under the conditions of $150 \mathrm{~g}$ ore, $293 \mathrm{~g} \mathrm{NaOH}, 300{ }^{\circ} \mathrm{C}$ for $1 \mathrm{~h}$, and different water usage of $210 \mathrm{~g}$ and 315 g, respectively)
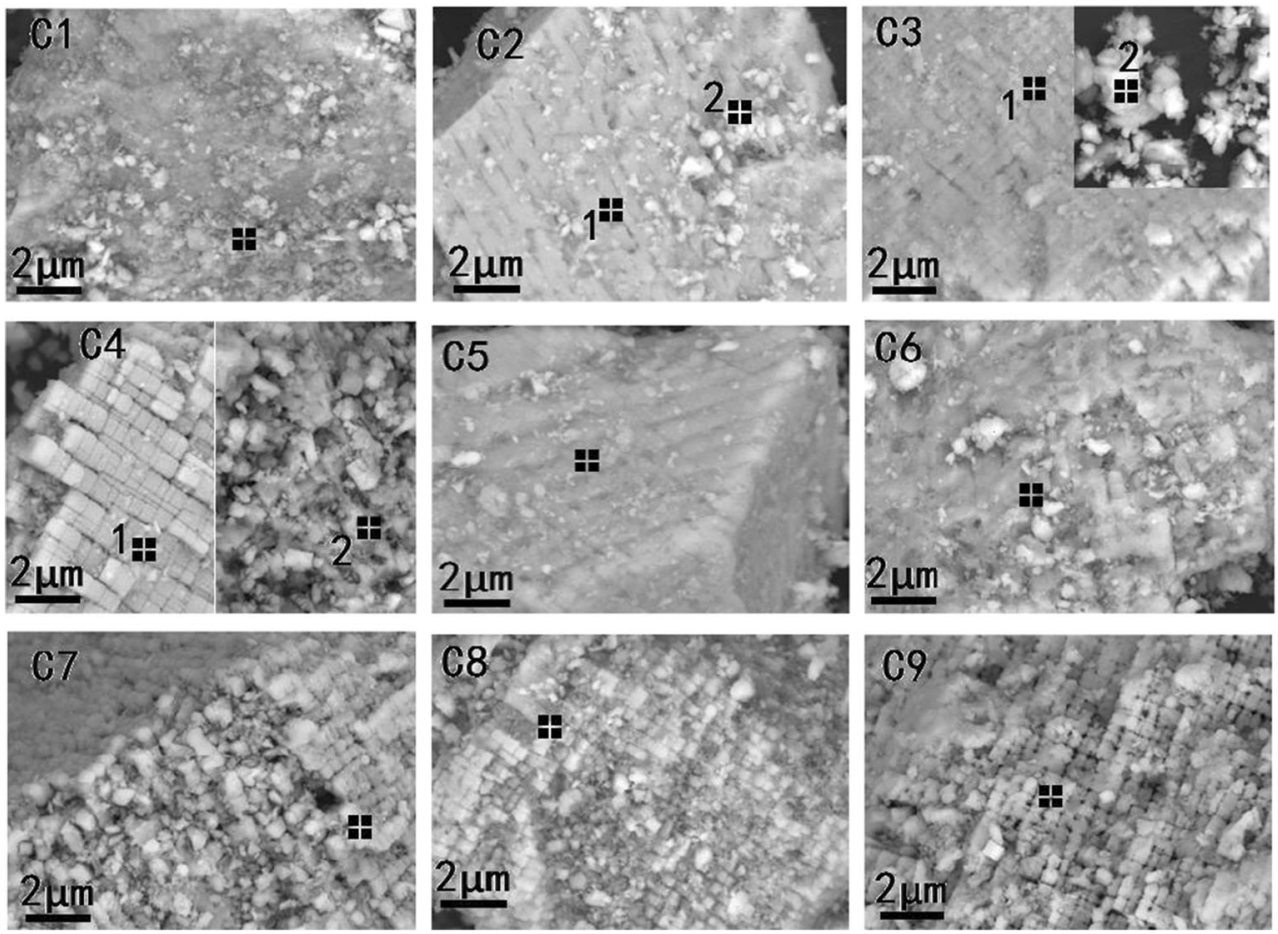
Table 6 Data of EDS measurements of concentrates C1-C9

\begin{tabular}{llllllllllllll}
\hline Sample & & C1 & C2-1 & C2-2 & C3-1 & C3-2 & C4-1 & C4-2 & C5 & C6 & C7 & C8 & C9 \\
\hline w\% & FeK & 47.92 & 52.97 & 55.80 & 63.03 & 47.66 & 60.15 & 58.88 & 58.33 & 60.18 & 59.45 & 48.39 & 60.41 \\
& TiK & 4.26 & 4.54 & 4.70 & 6.57 & 4.62 & 2.45 & 2.13 & 5.30 & 9.72 & 1.18 & 7.78 & 2.04 \\
\hline
\end{tabular}

reaction times were $15 \mathrm{~min}, 30 \mathrm{~min}, 60 \mathrm{~min}, 120 \mathrm{~min}$ and $180 \mathrm{~min}$, tailings T1-T5 in diameters of about $165 \mathrm{~nm}$, $110 \mathrm{~nm}, 94 \mathrm{~nm}, 65 \mathrm{~nm}$, and $63 \mathrm{~nm}$, and in lengths of about $883 \mathrm{~nm}, 1200 \mathrm{~nm}, 3294 \mathrm{~nm}, 4025 \mathrm{~nm}$, and $6382 \mathrm{~nm}$ were obtained, respectively, showing with the increase of reaction time, acicular substances in tailings gradually formed, and their length-diameter ratio increased; when the reaction temperatures were 320 and $360{ }^{\circ} \mathrm{C}$, tailings $\mathrm{T} 6$ and $\mathrm{T} 7$ in diameters of about $64 \mathrm{~nm}$ and $159 \mathrm{~nm}$, and in lengths of about $3273 \mathrm{~nm}$ and $1817 \mathrm{~nm}$ were obtained, showing with the increase of temperatures, the length-diameter ratio of acicular substances decreased, forming rod material; when the water usages were $210 \mathrm{~g}$, there were no acicular or rod substances in tailings $\mathrm{T} 8$, and when the water usages were $315 \mathrm{~g}$, there appeared rod substances in tailings T9, showing water providing environment for a crystal growing.

The data in Table 5 of EDS measurements of marking points on SEM photographs of tailings T1-T9 in Fig. 7 indicated that ilmenite erosion was a very complicated process. Titanium leaching of different particles, such as T1-1, T1-2, and T1-3, was inconsistent; except for titanium leaching, there was the leaching of other components, e.g., T1-2 contained $8.19 \% \mathrm{Si}$. The data of EDS measurements of tailings T1-T9 gave the regular conclusions that with the

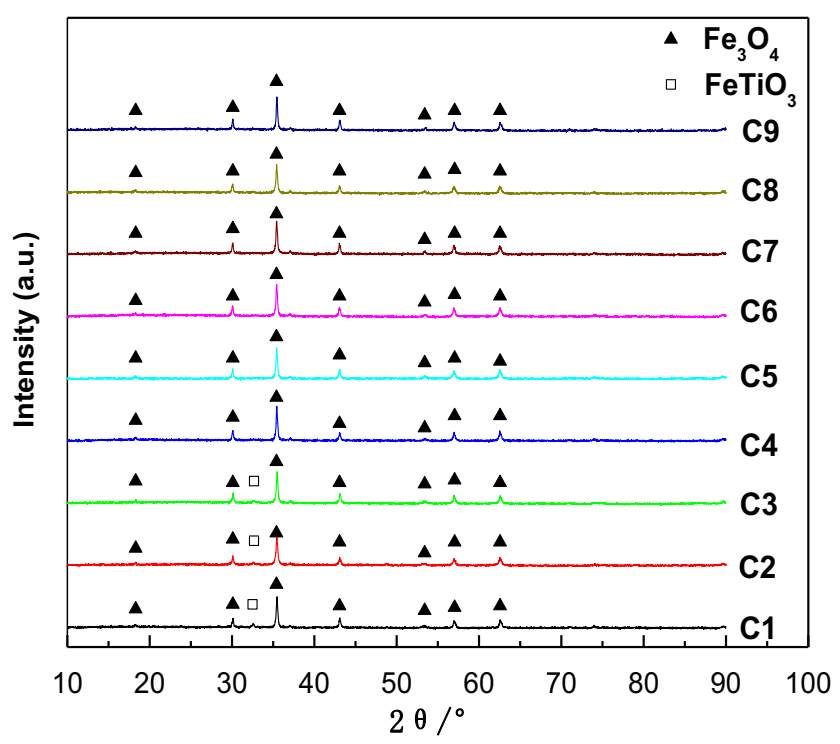

Fig. 6 XRD patterns of concentrates $\mathrm{C} 1-\mathrm{C} 9$ extension of reaction time, the increase of temperature, and water usage, the ratio of titanium to iron of T1-T9 increased (Table 7).

XRD spectra of tailings T1-T9 in Fig. 8 displayed that in tailings $\mathrm{T} 1-\mathrm{T} 9$, the characteristic diffraction peaks of ilmenite almost completely disappeared also, but the characteristic diffraction peaks of $\mathrm{Fe}_{3} \mathrm{O}_{4}$ existed strongly; this was because the magnetic tube was difficult to separate the $\mathrm{Fe}_{3} \mathrm{O}_{4}$ particles less than $10 \mu \mathrm{m}$ from tailings. In XRD spectra, the characteristic diffraction peak of $\mathrm{Na}_{2}(\mathrm{TiO})\left(\mathrm{SiO}_{4}\right)$ in space group of tetragonal $\mathrm{P} 4 / \mathrm{nmm}$ was found at $32.70^{\circ}$ in tailings $\mathrm{T} 1-\mathrm{T} 7$, the characteristic diffraction peak of $\mathrm{TiO}_{2}$ rutile in space group of tetragonal $\mathrm{P} 42 / \mathrm{mnm}$ was found at $27.46^{\circ}$ in tailings $\mathrm{T} 3-\mathrm{T} 6$ and the characteristic diffraction peak of $\mathrm{Na}_{4} \mathrm{Ti}_{5} \mathrm{O}_{12}$ in space group of monoclinic $\mathrm{C} 2 / \mathrm{m}$ was found at $14.07^{\circ}$ in tailing $\mathrm{T} 7$, respectively. These products were formed by the following reasons: under the caustic condition, $\mathrm{SiO}_{2}$ became $\mathrm{Na}_{4} \mathrm{SiO}_{4}$, and the Ti in $\mathrm{FeTiO}_{3}$ became $\mathrm{TiO}^{2+}, \mathrm{Na}_{2} \mathrm{TiO}_{3}, \mathrm{Na}_{2} \mathrm{Ti}_{2} \mathrm{O}_{5}$, and $\mathrm{Na}_{2} \mathrm{Ti}_{3} \mathrm{O}_{7} \cdot \mathrm{TiO}^{2+}$ substituted the $\mathrm{Na}^{+}$in $\mathrm{Na}_{4} \mathrm{SiO}_{4}$ and formed $\mathrm{Na}_{2}(\mathrm{TiO})\left(\mathrm{SiO}_{4}\right)$; the hydrolysis of $\mathrm{Na}_{2} \mathrm{TiO}_{3}, \mathrm{Na}_{2} \mathrm{Ti}_{2} \mathrm{O}_{5}$, and $\mathrm{Na}_{2} \mathrm{Ti}_{3} \mathrm{O}_{7}$ formed $\mathrm{TiO}_{2}$; the aggregation of $\mathrm{Na}_{2} \mathrm{Ti}_{2} \mathrm{O}_{5}$ and $\mathrm{Na}_{2} \mathrm{Ti}_{3} \mathrm{O}_{7}$ formed $\mathrm{Na}_{4} \mathrm{Ti}_{5} \mathrm{O}_{12}$.

This is a very complex hydrothermal reaction under high temperature, high pressure, and high alkalinity, so that the titanium-containing materials could be grown into crystals with certain shapes directionally.

\subsection{Effects of Reaction Conditions on Separation}

The effects of water usage, $\mathrm{NaOH}$ concentration, reaction temperature, and reaction time on the separation were investigated by single factor experiments.

Although after $15 \mathrm{~min}$ the leaching reaction could take place at $300{ }^{\circ} \mathrm{C}$, the mass transfer and diffusion rate of leached $\mathrm{Ti}$ in solid product $\mathrm{FeO}$ were slow. Therefore, at $60 \mathrm{~min}$, the purity and recovery of $\mathrm{TiO}_{2}$ of tailings $(18.49 \%$ and $38.24 \%$, respectively) were low, and so were the purity and recovery of $\mathrm{Fe}$ of concentrates $(59.28 \%$ and $80.12 \%$, respectively). The separation effect can only be achieved by extending the reaction time, as shown in Fig. 9a.

The effect of temperature on the separation was significant, as shown in Fig. 9b. By increasing the temperature, $\Delta G$ of the reaction was decreased and the random thermal 
Fig. 7 SEM images of tailings C1-C9
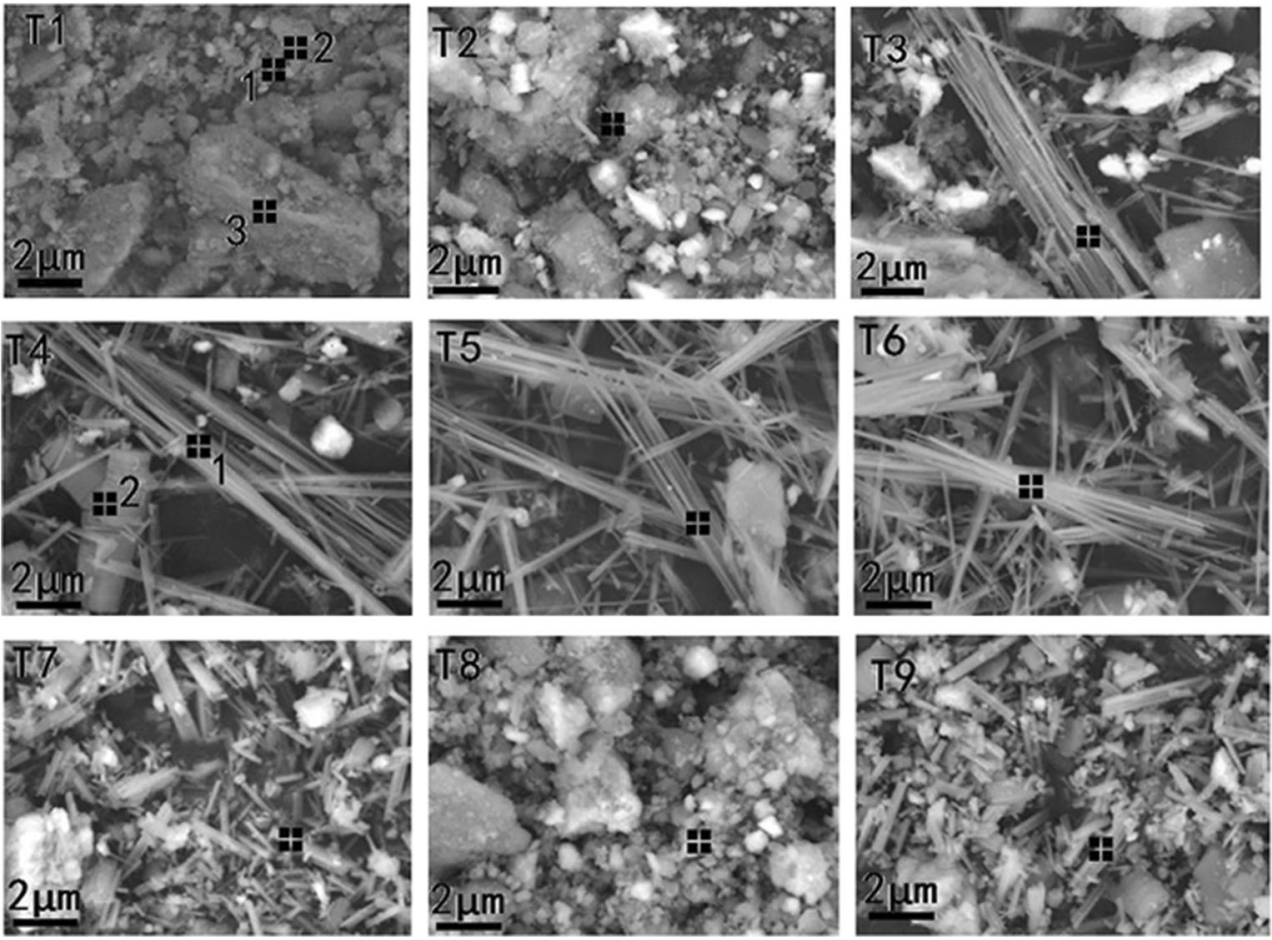

velocity of all particles was increased. When the leaching reaction took place at $360{ }^{\circ} \mathrm{C}$ for $60 \mathrm{~min}$, the purity and recovery of $\mathrm{TiO}_{2}$ of tailings increased simultaneously, which were $31.48 \%$ and $74.04 \%$, respectively; meanwhile, the purity and recovery of $\mathrm{Fe}$ of concentrates increased to $64.49 \%$ and $83.34 \%$, respectively. Therefore, increasing the temperature can improve the separation ability and efficiency.

The leaching reaction should be carried out in a $\mathrm{NaOH}$ solution of high concentration, higher than weight percent of $30 \%$ (see Fig. 9c). Except for as a reactant, the alkali was used to improve the polarity of the medium. However, $\mathrm{NaOH}$ concentration should not be too high; otherwise, the solution viscosity will increase, which will not be conducive to the deep penetration of $\mathrm{NaOH}$ into the mineral particles. Here, the appropriate concentration of $\mathrm{NaOH}$ was $40 \%$.
Figure 9d showed that an appropriate increase in water usage was beneficial to the separation between $\mathrm{Fe}$ and $\mathrm{Ti}$ in titanomagnetite. Although a higher water content increased the pressure of reactor leading to the increase of $\Delta G$ of the leaching reaction, it helped $\mathrm{NaOH}$ immersing, Ti leaching, and directionally crystallizing in dynamics.

According to the above experimental results, a good separation condition was that water usage was $410 \mathrm{~g}, \mathrm{NaOH}$ concentration $40 \%$, temperature $400{ }^{\circ} \mathrm{C}$, and reaction time $1 \mathrm{~h}$. Under this condition, the concentrate with purity values of $65.98 \% \mathrm{Fe}$ and $3.65 \% \mathrm{TiO}_{2}$ and the tailings with purity values of $28.78 \% \mathrm{Fe}$ and $32.09 \% \mathrm{TiO}_{2}$ were obtained.

The later work proved that this needle or bar titanium containing mixture (tailings) is a kind of additive for welding wire, which can improve the tensile strength and yield strength of welding seam.

Table 7 Data of EDS measurements of tailings T1-T9

\begin{tabular}{|c|c|c|c|c|c|c|c|c|c|c|c|c|c|}
\hline Sample & & $\mathrm{T} 1-1$ & T1-2 & T1-3 & $\mathrm{T} 2$ & $\mathrm{~T} 3$ & $\mathrm{~T} 4-1$ & $\begin{array}{l}\mathrm{T} 4- \\
2\end{array}$ & $\mathrm{~T} 5$ & T6 & $\mathrm{T} 7$ & $\mathrm{~T} 8$ & T9 \\
\hline \multirow[t]{2}{*}{$\mathrm{w} \%$} & $\mathrm{FeK}$ & 11.00 & 14.09 & 42.34 & 14.41 & 21.08 & 8.94 & 2.60 & 11.87 & 8.10 & 5.55 & 16.74 & 9.59 \\
\hline & $\mathrm{TiK}$ & 26.18 & 18.17 & 7.57 & 12.45 & 44.51 & 23.83 & 4.56 & 36.78 & 22.03 & 22.80 & 14.25 & 27.65 \\
\hline
\end{tabular}




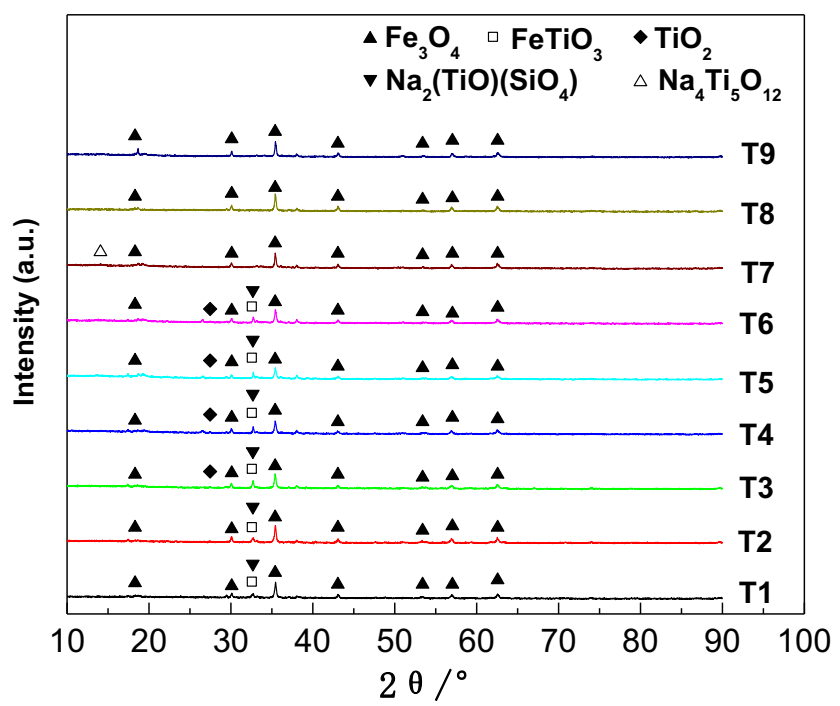

Fig. 8 XRD patterns of tailings T1-T9

\section{Conclusion}

The new process of "chemical-physical" combined mineral processing is used to treat titaniferous magnetite concentrate, which realizes the efficient separation of titanium and iron in the titaniferous magnetite concentrate. After separation, the iron grade of the concentrate is increased from 54 to more than $65 \%$, and $\mathrm{TiO}_{2}$ in the titanium tailings has been raised from 12.67 to over $32 \%$. It was thermodynamic feasible to leach titanium from titaniferous magnetite ore by $\mathrm{NaOH}$ aqueous solution under high temperature and high pressure. In the leaching process, the interfacial reaction rate was faster than the internal diffusion rate. After $\mathrm{NaOH}$ leaching and magnetic separation, in the concentrate, there were small $\mathrm{Fe}_{3} \mathrm{O}_{4}$ particles in shape of cube, and in the tailings, there were needle-like or rod-like mixtures containing titanium. At low temperature, an acicular Ti-containing mixture could form in a long time reaction, while at high temperature, a rod Ticontaining mixture could form in a short time reaction. In this leaching experiment, the pressure of the reaction system was controlled by water usage. When water usage was large, it was beneficial for $\mathrm{NaOH}$ to immerse deeply into the mineral particles, for Ti-ion to be leached from the mineral particles and for Ti-ion to crystallize directionally. This process solves the problem of low iron grade in the smelting furnace, realizes the efficient recovery of $\mathrm{TiO}_{2}$, opens a new way for the rational and efficient application of titanium resources in China, and
Fig. 9 Influences of reaction conditions on separation indices ((a) influence of reaction time, under the other conditions of $150 \mathrm{~g}$ ore, $300{ }^{\circ} \mathrm{C}, 40 \% \mathrm{NaOH}$, and $410 \mathrm{~g}$ water; (b) influence of reaction temperature, under the other conditions of $150 \mathrm{~g}$ ore, $40 \% \mathrm{NaOH}, 410 \mathrm{~g}$ water, and 60 min; (c) influence of $\mathrm{NaOH}$ concentration, under the other conditions of $150 \mathrm{~g}$ ore, $410 \mathrm{~g}$ water, and $340{ }^{\circ} \mathrm{C}$ for $1 \mathrm{~h}$; (d) influence of water usage, under the other conditions of $150 \mathrm{~g}$ ore, $293 \mathrm{~g} \mathrm{NaOH}$, and $300{ }^{\circ} \mathrm{C}$ for $1 \mathrm{~h}$.

-Fe purity of concentrate, $\bullet-\mathrm{Fe}$ recovery of concentrate, $\boldsymbol{\Delta}-\mathrm{TiO}_{2}$ purity of tailings, $\boldsymbol{\nabla}-\mathrm{TiO}_{2}$ recovery of tailings)
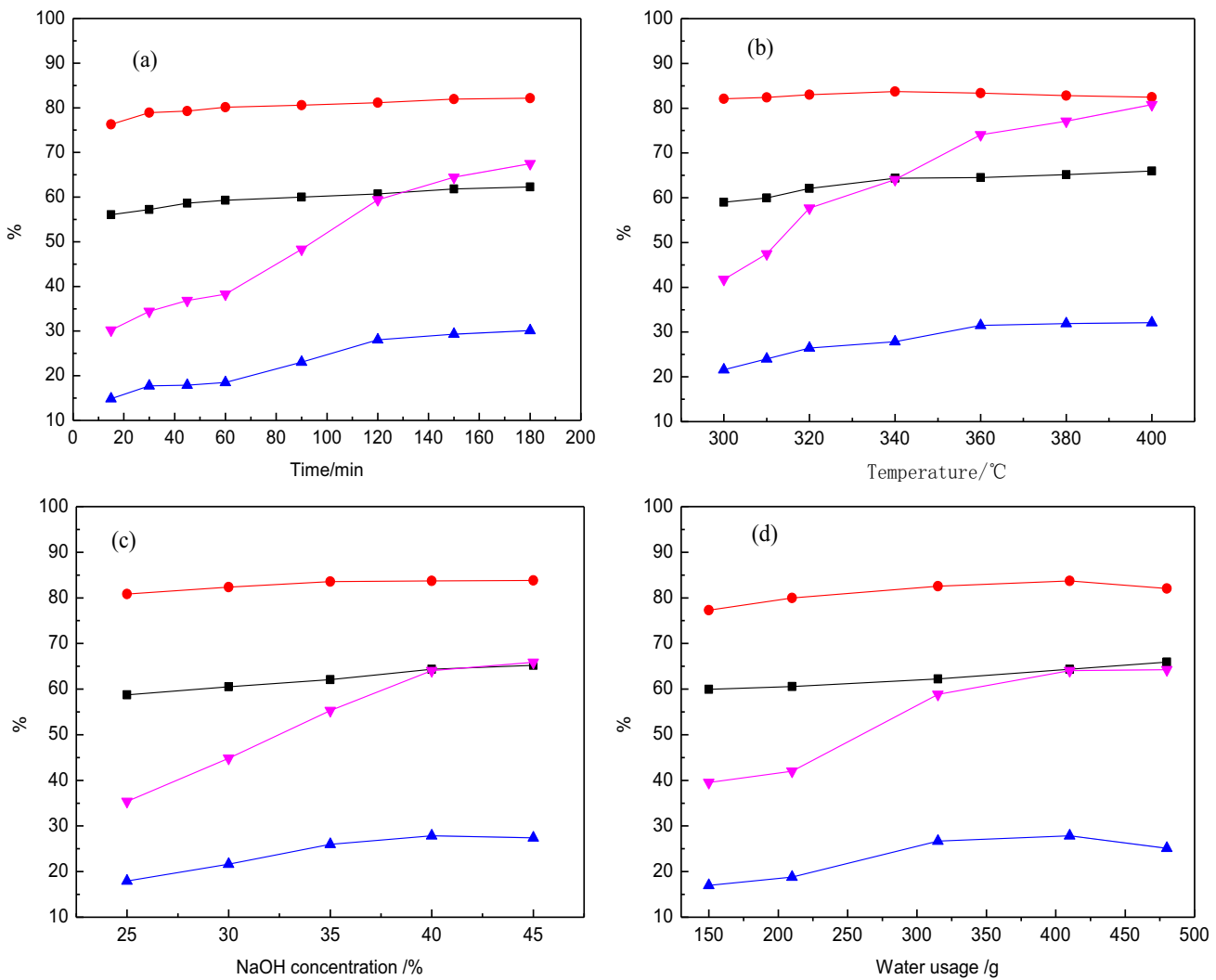
can realize the optimal allocation of mineral resources and promote economic growth.

Acknowledgements Thanks to the people helping with this work, and acknowledges the valuable suggestions and reviews from the peer reviewers.

\section{Compliance with Ethical Standards}

Conflict of Interest The authors declare no competing interests.

Open Access This article is licensed under a Creative Commons Attribution 4.0 International License, which permits use, sharing, adaptation, distribution and reproduction in any medium or format, as long as you give appropriate credit to the original author(s) and the source, provide a link to the Creative Commons licence, and indicate if changes were made. The images or other third party material in this article are included in the article's Creative Commons licence, unless indicated otherwise in a credit line to the material. If material is not included in the article's Creative Commons licence and your intended use is not permitted by statutory regulation or exceeds the permitted use, you will need to obtain permission directly from the copyright holder. To view a copy of this licence, visit http://creativecommons.org/licenses/by/4.0/.

\section{References}

1. Wang YM, Yuan ZF, Guo ZC, Tan QQ, Li ZY, Jiang WZ (2008) Reduction mechanism of natural ilmenite with graphite. Trans Nonferrous Metals Soc China 18:962-968. https://doi.org/10. 1016/S1003-6326(08)60166-1

2. Liu S, Guo Y, Qiu G, Jiang T, Chen F (2014) Solid-state reduction kinetics and mechanism of pre-oxidized vanadium-titanium magnetite concentrate. Trans Nonferrous Metals Soc China 24:33723377. https://doi.org/10.1016/s1003-6326(14)63479-8

3. Tan P, Hu HP, Zhang L (2011) Effects of mechanical activation and oxidation-reduction on hydrochloric acid leaching of Panxi ilmenite concentration. Trans Nonferrous Metals Soc China 21:1414-1421. https://doi.org/10.1016/s1003-6326(11)60875-3

4. Wang YM, Wang XW, He YH, Lou TP, Sui ZT (2008) Isothermal precipitation and growth process of perovskite phase in oxidized titanium bearing slag. Trans Nonferrous Metals Soc China 18:459 462. https://doi.org/10.1016/S1003-6326(08)60081-3

5. Si XG, Lu XG, Li CW, Li CH, Din WZ (2012) Phase transformation and reduction kinetics during the hydrogen reduction of ilmenite concentrate. Int J Miner Metall Mater 19:384-390. https://doi. org/10.1007/s12613-012-0568-4

6. Saikat S, Manik CG, Tapan KB, Siddhartha M, Rajib D (2013) Mineralogy and carbothermal reduction behaviour of vanadiumbearing titaniferous magnetite ore in Eastern India. Int $\mathrm{J}$ Miner Metall Mater 20:917-924. https://doi.org/10.1007/s12613-0130815-3
7. Eungyeul P, Oleg O (2004) Reduction of titania-ferrous ore by hydrogen. ISIJ Int 44:990-1005. https://doi.org/10.2355/ isijinternational.44.999

8. Kucukkaragoz CS, Eric RH (2006) Solid state reduction of a natural ilmenite. Miner Eng 19:334-337. https://doi.org/10.1016/j.mineng. 2005.09.015

9. Wang Y, Yuan Z, Matsuura H, Tsukihashi F (2009) Reduction extraction kinetics of titania and iron from an ilmenite by $\mathrm{H} 2-\mathrm{Ar}$ gas mixtures. ISIJ Int 49:164-170. https://doi.org/10.2355/ isijinternational.49.164

10. Krasikov SA, Maiorov LA, Ponomarenko AA, Zhidovinova SV, Savvinova AA (2011) Separation of elements in processing titanomagnetite concentrates. Steel Transl 41:752-755. https://doi. org/10.3103/S0967091211090105

11. Hu T, Lv XW, Bai CG, Lun ZG, Qiu GB (2013) Reduction behavior of Panzhihua titanomagnetite concentrates with coal. Metall Mater Trans B Process Metall Mater Process Sci 44:252-260. https://doi.org/10.1007/s11663-012-9783-7

12. Hu T, Sun T, Kou J, Geng C, Wang X, Chen C (2017) Recovering titanium and iron by co-reduction roasting of seaside titanomagnetite and blast furnace dust. Int J Miner Process 165: 28-33. https://doi.org/10.1016/j.minpro.2017.06.003

13. Samanta S, Mukherjee S, Dey R (2015) Upgrading metals via direct reduction from poly-metallic titaniferous magnetite ore. J Miner Met Mater Soc 67:467-476. https://doi.org/10.1007/s11837-0141203-9

14. Chen DS, Song B, Wang LN, Qi T, Wang Y, Wang WJ (2011) Solid state reduction of Panzhihua titanomagnetite concentrates with pulverized coal. Miner Eng 24:864-869. https://doi.org/10. 1016/j.mineng.2011.03.018

15. Jena B, Dresler W, Reilly I (1995) Extraction of titanium, vanadium and iron from titanomagnetite deposits at pipestone lake, Manitoba, Canada. Miner Eng 8:159-168

16. Zhao LS, Wang LN, Qi T, Chen DS, Zhao HX, Liu YH (2014) A novel method to extract iron, titanium, vanadium, and chromium from high-chromium vanadium-bearing titanomagnetite concentrates. Hydrometallurgy 149:106-109. https://doi.org/10.1016/j. hydromet.2014.07.014

17. Chen DS, Zhao LS, Liu YH, Qi T, Wang JC, Wang LN (2013) A novel process for recovery of iron, titanium, and vanadium from titanomagnetite concentrates: $\mathrm{NaOH}$ molten salt roasting and water leaching processes. J Hazard Mater 244-245:588-595. https://doi. org/10.1016/j.jhazmat.2012.10.052

18. Silberberg MS (2000) Chemistry: the molecular nature of matter and change (second edition) $[\mathrm{M}]$. The McGraw-Hill Companies, Inc

19. Haverkamp RG, Kruger D, Rajashekar R (2016) The digestion of New Zealand ilmenite by hydrochloric acid. Hydrometallurgy 163: 198-203. https://doi.org/10.1016/j.hydromet.2016.04.015

Publisher's Note Springer Nature remains neutral with regard to jurisdictional claims in published maps and institutional affiliations. 